\title{
MANAGEMENT OF TIME AND COST CONTINGENCIES IN CONSTRUCTION PROJECTS: A CONTRACTOR PERSPECTIVE
}

\author{
José I. ORTIZ1, Eugenio PELLICER ${ }^{2 *}$, Keith R. MOLENAAR ${ }^{3}$ \\ ${ }^{1}$ Area of Industrial Engineering, Universidad Carlos III, Av. de la Universidad 30, 28911 Leganés, Madrid, Spain \\ ${ }^{2}$ School of Civil Engineering, Universitat Politècnica de València, Camino de Vera s/n, 46022, Valencia, Spain \\ ${ }^{3}$ Department of Civil, Environmental and Architectural Engineering, University of Colorado Boulder, UCB 428, \\ Boulder, CO 80309-0428, United States
}

Received 29 July 2017; accepted 08 March 2018

\begin{abstract}
The management of threats and opportunities plays a key-role in enhancing project performance. However, there is a gap in literature concerning how general contractors manage threats and opportunities in construction projects, in particular in the use of time and cost contingencies. This research partially addresses this gap through a case study of two large Spanish construction companies. The research presented two key factors determining how the contractors analyzed manage time and cost contingencies: project objectives and existing mistrust among the contractor's team members. The research also found that managers use time and cost contingencies not only to manage threats, but also as tools for managing opportunities, thereby providing insight into a previously undescribed form of contingency: the negative contingency. The research results enable a better understanding of the actual behavior of general contractors, which contributes to paving the way for developing enhanced methods for contingencies management.
\end{abstract}

Keywords: contractor, contingency, opportunity, risk, Spain, threat, uncertainty.

\section{Introduction}

Threats, or risks with negative impacts on project performance, take place in every economic sector (PMI 2013). The construction industry, in particular, presents high levels of negative risks (Seung, Hyung 2004; Ballard 2005; Russell et al. 2012). The materialization of threats may jeopardize the achievement of project objectives (project completion period, fulfillment of scope, achievement of specifications, profit, etc.). Yet, certain threats have to be assumed and accepted. Examples include threats that have not been identified (unknowns-unknowns) and threats that have been identified but cannot be fully mitigated (known-unknowns) (PMI 2013). Literature characterizes the concept of contingency within the context of the strategies to face accepted negative risks: "The most common active acceptance strategy is to establish a contingency reserve, including amounts of time, money, or resources to handle the risks" (PMI 2013, p. 345). Common nomenclatures for this concept are "contingency" and "buffer". Contingency is more common when money is the resource. Buffer is a more common term when the reserve is of a different nature (e.g., time or materials). However, both terms will be considered equivalent in this research, which is consistent with industry standards (PMI 2013).

Previous literature has widely discussed the concept of time and cost contingency as a threats-related tool, although from the perspective of owners, rather than contractors. Some efforts focus on methodologies to size contingencies that could improve the current practice. Ford (2002) and Diab et al. (2017) are the only studies identified in the literature describing, though only partly, how contractors actually manage threats-related cost contingencies during the construction phase. However, Ford (2002) and Diab et al. (2017) focused only on sizing cost contingency; hence, other aspects of the actual practices of contractors on time and cost contingency management during the construction phase remain undiscussed.

Notwithstanding, risk is a two-sided concept that includes both threats (i.e. negative risks) and opportunities (i.e. positive risks) (Hillson 2002; PMI 2013). Even though several authors have postulated that the management of opportunities is critical for project success (Hillson 2002; Leach 2003; Godfrey 2004; Molenaar et al. 2010; Laryea,

*Corresponding author. E-mail: pellicer@upv.es 
Hughes 2011; PMI 2013; Ortiz et al. 2014; Eldosouky et al. 2014), no references have been found about how general contractors actually manage opportunities during the construction phase. Another aspect that some authors consider as critical to success is trust among the project team members; indeed, Solomon and Flores (2001) consider that trust leads to cooperation, while Lofton and Monteith (2004) see cooperation as a source of competitive advantages.

Successful efforts towards enhanced contingency management rely on the ability to accurately describe reality. However, there is a void in the literature regarding how contractors actually manage threats and opportunities during the construction phase with time and cost contingencies. The research in this paper aims to help describe how general contractor manage time and cost contingencies during the construction phase of projects, thus filling this gap, at least partially, by answering two primary research questions: (Q1) What factors determine contractors' managerial approach to time and cost contingency management?; and (Q2) How do general contractors price opportunities? However, it was not the objective of this research neither to address in full how contractors manage time and cost contingencies nor to come up with a quantitative approach to model opportunities and threats in the construction project. Therefore, the specific quantitative methods that contractors use to size time and cost contingencies during the construction phase have not been addressed. Through increased knowledge of how contractors actually manage time and cost contingencies, which is the gap this research intends to fill out, improvements (e.g. quantitative methods to model contingencies management based on the current practice) might be better prescribed in the future.

This research presents a literature review on the attributes of time and cost contingencies. This review identifies attributes, which form variables for the development of a case-study protocol that challenges ideas provided in the literature. Next, a multi-case study design, including selection of companies, sources of data, and key conditions to be achieved by the research design, is introduced. Then the findings are presented and discussed. Finally, contributions of the research to the body of knowledge and its practical implications and limitations, form the conclusions of the research.

\section{Literature review}

As mentioned above, literature has discussed the concept of time and cost contingency as a threats-related tool, although from the perspective of owners, rather than contractors. Hence, due to the scarcity or lack of specific references focusing on the domain analyzed (i.e. time and cost contingency management in the construction phase from the perspective of general contractors), references related to close domains (e.g. owners, bidding process, etc.) were taken into account in order to shape the theoretical framework for the research. Table 1 organizes and summarizes the references used.
The concept of contingency can be generically defined as a reserve for unexpected events (Howell 2012). When discussing contingency, the construction literature also refers to the nature of the reserve (time, money, capacity, specifications or inventories) (PMI 2013; Godfrey 2004), its purpose (to absorb uncertainty and variation or to hedge risks), and its final goal (to protect certain project objectives) (Querns 1989; Günhan, Arditi 2007; Barraza 2010). In addition to these aspects, the PMI (2013) and Taroun (2014) also highlight the operational use of contingency within the global process of risk management as a tool to actively manage risks. Regarding the party that defines and manages the contingency, Günhan and Arditi (2007) describe an owner's contingency, a contractor's contingency and a designer's contingency. Contingencies can be set at various phases of the project development process. Contractors set time and cost contingencies during bidding processes (Smith, Bohn 1999; Laryea, Hughes 2011; Eldosouky et al. 2014; Asgari et al. 2016) and manage them during the construction phase (Ford 2002; Diab et al. 2017). Some contributions propose or discuss methods to determine the initial size of contingencies (Yeo 1990; Seung, Hyung 2004; Barraza 2010; Idrus et al. 2011; Bhargava et al. 2017). Others focus on how to dynamically adapt the amount of contingency to the existing risk throughout the project (Godfrey 2004; Noor, Tichacek 2009; Howell 2012). A number of studies provide information about the decision-makers who are involved in contingencies management (Ford 2002; Laryea, Hughes 2011) or about the transparency of contingencies (Smith, Bohn 1999; Leach 2003; Chan, Au 2009; Laryea, Hughes 2011; Goldratt 1997; Yeo 1990; Thompson, Perry 1992; Baccarini 2004). However, despite the previously mentioned relevancy of opportunities management, most of the authors use the term "risk" synonymously with the term "threat" (Dake 1992; Chapman, Ward 2003). Given the prevalence of these definitions, literature contains a bias that views contingency as a tool for threats management rather than a tool to capitalize on opportunities. In fact, only one effort was found analyzing the connection between opportunities and cost contingencies; indeed, Eldosouky et al. (2014) claim that contractors should assess not only threats, but also opportunities in order to properly size cost contingency during the bidding processes. Therefore, the fact that risk is a two-sided concept (i.e. threats and opportunities), allows exploring the potential role of time and cost contingencies to manage opportunities.

Thus, the theoretical framework for this research relies on four groups of variables related to time and cost contingency management that have been drawn from existing literature: decision makers, transparency and sizing of contingency, and opportunities management. The following paragraphs address each group.

Ford (2002) states that project managers are the main decision-makers. Laryea and Hughes (2011) challenge this assertion highlighting that several decision-makers may act, either in a coordinated manner or alone. To assess both the motivations of the decision-makers and the 
Table 1. Summary of references

\begin{tabular}{|c|c|c|}
\hline Subject & Approach & References \\
\hline \multirow[t]{6}{*}{ Concept of risk } & Risk in construction field & $\begin{array}{l}\text { Seung and Hyung (2004); Ballard (2005); Russell et al. } \\
\text { (2012) }\end{array}$ \\
\hline & $\begin{array}{l}\text { Double side of risk (i.e. opportunities } \\
\text { and threats) }\end{array}$ & Hillson (2002); PMI (2013) \\
\hline & $\begin{array}{l}\text { Opportunities management and } \\
\text { success }\end{array}$ & $\begin{array}{l}\text { Hillson (2002); Leach (2003); Godfrey (2004); Molenaar } \\
\text { et al. (2010); Laryea and Hughes (2011); PMI (2013); Ortiz } \\
\text { et al. (2014); Eldosouky et al. (2014) }\end{array}$ \\
\hline & Trust and success & Solomon and Flores (2001); Lofton and Monteith (2004) \\
\hline & Threats management and contingency & $\begin{array}{l}\text { Dake (1992); Chapman and Ward (2003); Ballesteros-Pérez } \\
\text { et al. (2014) }\end{array}$ \\
\hline & $\begin{array}{l}\text { Opportunities management and } \\
\text { contingency }\end{array}$ & Chan and Au (2009); Eldosouky et al. (2014) \\
\hline \multirow[t]{3}{*}{ Concept of contingency } & Definition & Howell (2012); PMI (2013) \\
\hline & Nature of the reserve & PMI (2013); Godfrey (2004) \\
\hline & Use and purpose of the contingency & $\begin{array}{l}\text { Querns (1989); Günhan and Arditi (2007); Barraza (2010); } \\
\text { PMI (2013); Taroun (2014) }\end{array}$ \\
\hline \multirow[t]{9}{*}{$\begin{array}{l}\text { Management of } \\
\text { contingency }\end{array}$} & $\begin{array}{l}\text { Construction companies and actual } \\
\text { management }\end{array}$ & Ford (2002); Eldosouky et al. (2014) \\
\hline & Party defining the contingency & Günhan and Arditi (2007) \\
\hline & Bidding process and contingency & $\begin{array}{l}\text { Smith and Bohn (1999); Laryea and Hughes (2011); } \\
\text { Eldosouky et al. (2014); Asgari et al. (2016) }\end{array}$ \\
\hline & Construction phase and contingency & Ford (2002); Diab et al. (2017) \\
\hline & Methods to size the contingency & $\begin{array}{l}\text { Yeo (1990); Seung and Hyung (2004); Barraza (2010); Idrus } \\
\text { et al. (2011); Bhargava et al. (2017) }\end{array}$ \\
\hline & $\begin{array}{l}\text { Evolution of the contingency } \\
\text { throughout the project }\end{array}$ & Godfrey (2004); Noor and Tichacek (2009); Howell (2012) \\
\hline & Decision-makers on contingency & Ford (2002); Laryea and Hughes (2011); Russell et al. (2012) \\
\hline & Hidden and explicit contingency & $\begin{array}{l}\text { Smith and Bohn (1999); Leach (2003); Chan and Au (2009); } \\
\text { Laryea and Hughes (2011); Goldratt (1997); Yeo (1990); } \\
\text { Thompson and Perry (1992); Baccarini (2004) }\end{array}$ \\
\hline & Generic and specific contingency & $\begin{array}{l}\text { Smith and Bohn (1999); Leach (2003); Chan and Au (2009); } \\
\text { Laryea and Hughes (2011); Yeo (1990); Thompson and } \\
\text { Perry (1992); Baccarini (2004) }\end{array}$ \\
\hline
\end{tabular}

determinants of their decisions, it is relevant to take into consideration that different professional profiles would show varying degrees of risk aversion (Russell et al. 2012). It is also relevant to consider the decision-makers' view about how risk evolves throughout the project. In this regard, Howell (2012) provides an interesting insight in that decision-makers often underestimate risk at the beginning of the projects and, therefore, underestimate contingency.

Contingencies can be hidden or transparent. Contingencies may be hidden within cost estimates and work schedules through inflated unit costs or longer task durations (Smith, Bohn 1999; Leach 2003; Chan, Au 2009; Laryea, Hughes 2011). Alternatively, they may be explicit, as a fixed percentage line added to the base estimate (Yeo 1990; Thompson, Perry 1992; Baccarini 2004) or as time buffer allocated at some point along the critical path of the schedule (Goldratt 1997). Furthermore, contingencies may be explicitly defined for each cost item or task (Smith, Bohn 1999; Leach 2003; Chan, Au 2009; Laryea, Hughes 2011), or for the whole project as a generic amount of time or money (Yeo 1990; Thompson, Perry 1992; Baccarini 2004).

Chan and $\mathrm{Au}$ (2009) found that certain risk factors may cause contractors to either raise their bid price (i.e. they would add a positive cost contingency to the base case in order to hedge threats) or to reduce it (i.e. they would deduct a negative cost contingency from the case base in order to price opportunities). For example, knowledge of a specific market as well as behavior of competitors can be a key issue to establish these contingencies (BallesterosPérez et al. 2014, 2016). Chapman and Ward (2003) move beyond the observation and present the case for the joint management of both opportunities and threats. These groups of variables informed the research method. Given the abovementioned current gap in the contingency management body of knowledge, this research seeks to contribute to document - at least partially - how construction companies manage contingences during the construction phase of the project. 


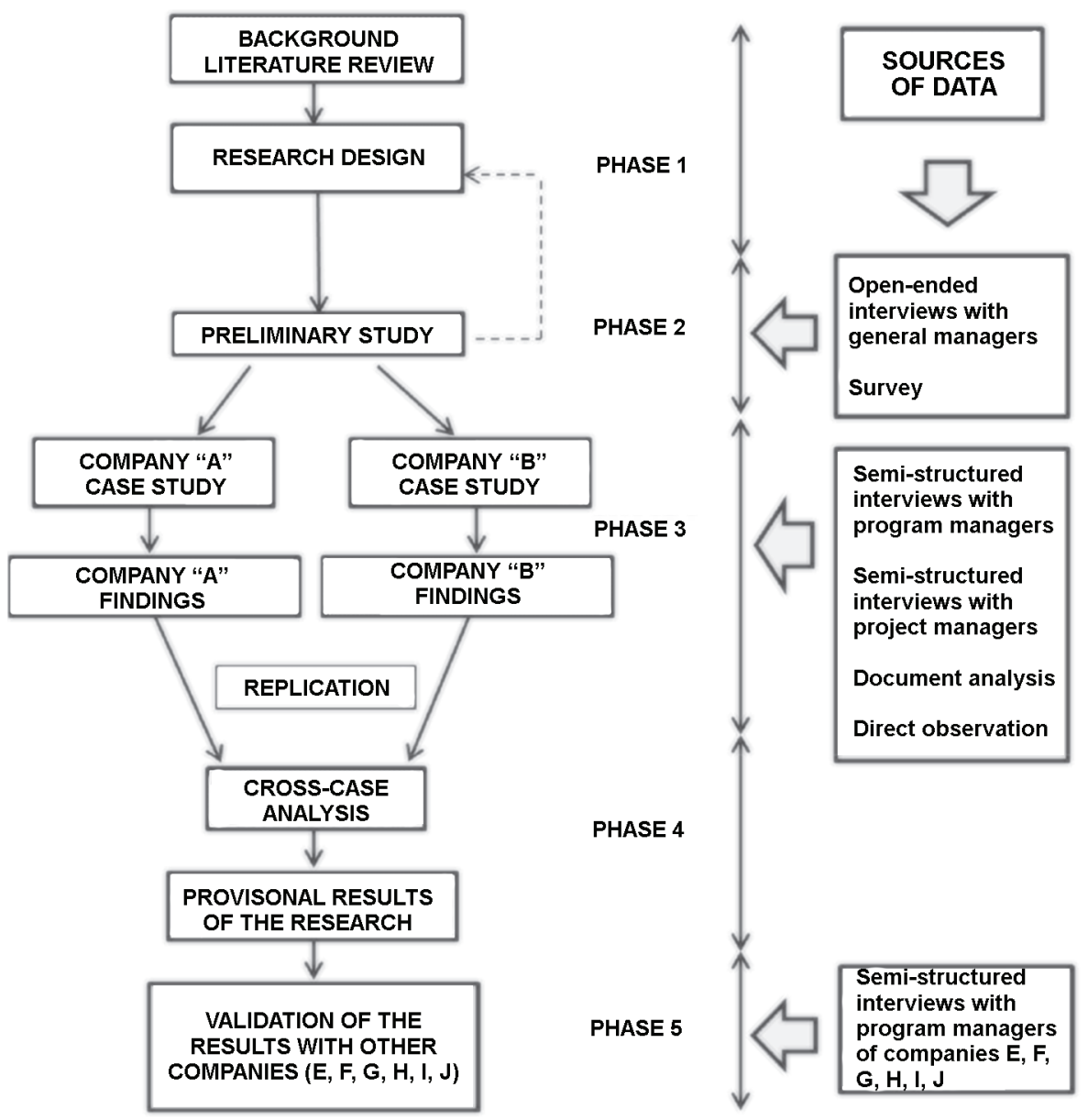

Figure 1. Outline of the research process

\section{Research method}

The research team decided to conduct a multi-case approach. Two different construction contractors were chosen as the units of analysis; case study selection is addressed in section 3 of this document in detail. In order to guarantee the methodological and scientific quality of the research, the case study approach was designed to meet four conditions (Yin 2009): (a) construct validity, (b) internal validity, (c) external validity, and (d) reliability. The use of two cases enabled the researchers to apply replication logic (both literal and theoretical), which increases the external validity of the results in a case study approach (Yin 2009). This approach allows the possibility to analytically generalize the results in the construction management research domain (Yin 2009; Taylor et al. 2011; Miles et al. 2013).

The research process followed five primary phases (see Figure 1): (1) Literature review and research design; (2) preliminary study; (3) data collection and analysis in both companies; (4) cross-case analysis; and (5) external validation. The research team developed a case study protocol that guided them throughout the data collection process (Yin 2009). The protocol consists of the following sections: (1) research project overview (objectives, research questions, etc.); (2) operating procedures (introduction of the research team to the interviewees, access to jobsites, sources of data, confidentiality forms, material resources required, tentative schedule of the interviews, etc.); (3) guidelines for the Phase 2 interviews with the general managers; (4) the Phase 2 survey questionnaire; and (5) interviews guidelines and questions for program and project managers (Phase 3 ).

Phase 2 started with two open-ended interviews with the general managers of companies $\mathrm{A}$ and $\mathrm{B}$. The general manager of company $\mathrm{A}$ is a building engineer. He is the main shareholder of the company and a member of the board of directors. The general manager of company B is a civil engineer, shareholder and also a member of the board of directors. Both general managers have over 20 years of experience in the construction industry. These interviews were as much a source of data as the kick-off meetings of the field research. At the start of these interviews, the authors thoroughly described the research project, its objectives and the support required from companies A and $B$. The general managers contributed their views regarding generic aspects of the research topic, which are discussed in the Research Findings and Discussion section.

In Phase 2, 53 program and project managers from company A and 203 from company B were invited to 
participate in a survey questionnaire. One hundred fortyone (141) valid responses were collected, 47 from company A and 94 from company B, having a sample error of $4.9 \%$ and $7.4 \%$, respectively, for a $95 \%$ confidence level. These response rates are acceptable for social sciences research (Teddlie, Tashakkori 2009). The survey results are discussed in the Research Findings and Discussion section.

Phase 3 involved the collection of documents, direct observations and semi-structured interviews carried out with program and project managers from each company. The size of project managers' sample was based on saturation (i.e., interviews continued until no new information was gained) (Guest et al. 2006); six project managers and one program manager from each company were interviewed. The interviews were face-to-face and generally lasted more than one hour. The interviews took place in the working environment of the interviewees (Woodside 2010). Company A's project managers were coded A2 to A7 and company B's were similarly coded B2 to B7. Program managers were coded as A1 and B1. The interview sample was intentional. The selection criteria were such that the interviewees needed to be university graduates in engineering or architecture with at least 10 years of experience on the construction industry and two years in their current position. Individuals without a university degree were included if they had at least 15 years of experience in their respective position.

To ensure a smooth functioning of interviews, interviewees could raise any information on the topic that they considered to be relevant. The interviews were not taped, but a written transcript of them was created and recorded in the evidence database jointly through notes and narrations of the interviewer (Woodside 2010). In order to ensure the traceability of results, a code was assigned to every entity of data (survey and interviews answers, documents, transcripts, notes, narrations, etc.).

The data analysis followed the approach of Miles et al. (2013), who view the qualitative data analysis process as three concurrent and interactive activity flows: data condensation, data presentation, and extraction of conclusions. The generation and display of condensed data was an essential aspect of the analysis. Condensing data into simpler units transforms the raw data into categories which are consistent with the research questions. The condensed data could be displayed through matrices with rows and columns to fit with such categories. These matrices facilitated analysis and pattern identification. The specific analysis tools that were used were "pattern matching" and "explanation building" (Yin 2009). The output of the Phase 3 was the findings of each individual case (A and B).

The cross-case analysis (Phase 4) compared the findings of the individual cases and extracted propositions that enabled the formulation of provisional research results. The extraction of these results was supported by literal and theoretical replication logic. The final results were derived from 141 survey responses, 16 interviews (two interviewees were general managers, two program managers and 12 project managers), more than one hundred hours of direct observation and a vast amount of document analysis. The analysis consisted of condensing data to perform pattern matching and cross-case analysis.

To address external validity, the results were explored through semi-structured interviews with program managers from six additional construction companies (companies E, F, G, H, I and J, as previously stated) (Phase 5). These interviews scrutinized a number of statements on a 5-point ordinal scale. Each statement was directly related to the specific results shown later in Table 4 . The program manager was asked about his/her level of agreement with each statement (strongly disagree (1); disagree (2); neutral (3); agree (4); strongly agree (5)). At the conclusion of the six interviews, the authors calculated the median of the six answers to each question, evaluating the research results according to the following criteria: Strong validity $(\mathrm{Me} \geq 4)$; acceptable validity $(3 \leq \mathrm{Me}<4)$; weak validity $(2 \leq \mathrm{Me}<3)$; non-valid $(1 \leq \mathrm{Me}<2)$. For each of the statements, the interviewees were encouraged to add any comment or opinion on the matter at hand. The conclusion was that all results had strong validity, since the median of the interviewees' answers was greater than or equal to 4 in all cases. Phase 5 produced the definitive results of the research, which are presented in the following section later.

\section{Case study selection}

The selection of companies was intentional (Yin 2009). As previously stated, the construction industry presents high levels of risks. Time and cost contingencies are tools to face accepted risks. Because a company has to properly manage risks in order to succeed in this industry, the study of any leading company, with a long history of success within the industry, could provide relevant insights about the phenomena. For this reason, the cases were selected to meet criteria 3 and 6 in Table 2. Additionally, the selection of companies aimed to facilitate literal and theoretical replication (Yin 2009). To facilitate literal replication, two companies with similar features regarding the first nine criteria in Table 2 were chosen. To facilitate theoretical replication, the two selected companies present opposing characteristics in regard to, at least, one characteristic criterion. The research team decided that the key opposing characteristic was the type of relationship between the construction company and its clients, which is a key factor in contingency management (see criterion 10 in Table 2). Company A was chosen because it is an integrated company; it works exclusively for the developer of its corporate group and it obtains construction projects without participating in any kind of open bidding (Pellicer et al. 2016). Company B was chosen because it is a nonintegrated company. Company B procures its contracts in competitive bids to build the facility. Company B generally works in a traditional design-bid-build delivery environment, which is the most common strategy in the Spanish construction industry (de la Cruz et al. 2006; Pellicer, Victory 2006; Oviedo-Haito et al. 2014; Pellicer et al. 2016). 
Table 2. Characteristics of companies A and B in relation to the selection criteria

\begin{tabular}{|c|c|c|}
\hline Selection criteria & Company A & Company B \\
\hline $\begin{array}{l}\text { 1. Field of specialization: civil engineering and building construction (residential, } \\
\text { industrial and commercial) general contractors }\end{array}$ & $\checkmark$ & $\checkmark$ \\
\hline 2. Location: Spain & $\checkmark$ & $\checkmark$ \\
\hline 3. Year of incorporation: prior to 1990 & 1985 & 1990 \\
\hline 4. Number of housing units built over the last 20 years (more than 7,000 ) & 16,700 & 9,000 \\
\hline 5. Annual revenues (more than $50 \mathrm{M} €$ ) & $85 \mathrm{M} €$ & $300 \mathrm{M} €$ \\
\hline 6. Creditworthiness: no bankruptcy history over the last 20 years & $\checkmark$ & $\checkmark$ \\
\hline 7. Convenience: projects in the Madrid area & $\checkmark$ & $\checkmark$ \\
\hline 8. Interest of the research: high & $\checkmark$ & $\checkmark$ \\
\hline 9. Size (according to EU 2003): large & $\checkmark$ & $\checkmark$ \\
\hline 10. Level of integration (\% of contracts with internal clients): uneven & $100 \%$ & $10 \%$ \\
\hline
\end{tabular}

The number of companies studied relates to the complexity of the expected results (Yin 2009). Yin's approach yields that for a descriptive theory - as in this research two cases can be sufficient. Taylor et al. (2011) claimed that showing the applicability of the research results in different scenarios from the ones analyzed is a way to increase their external validity. Therefore, in order to contrast the results of research at other companies, different semi-structured interviews were carried out with program managers from six different construction companies (named E, F, G, H, $\mathrm{I}$ and J, considering that $\mathrm{C}$ and $\mathrm{D}$ were not used). These six contractors were selected to increase the breadth of integration when compared to companies A and B. Table 3 describes the characteristics of these six companies.

On the basis of the companies studied, the domain to which the research results can be generalized is: (1) Spanish general contractors; (2) the construction phase of the infrastructure life-cycle; (3) civil engineering and building construction; (4) large and medium-sized companies; and (5) varying degrees of integration between the developer and the contractor.

\section{Research findings and discussion}

As described earlier, the selection of companies A and B was intentional and aimed at facilitating both literal and analytical replication. Nonetheless, even though analytical replication was included in the case-study research design and data collection efforts, all the theoretical constructs that are presented below have been developed only by means of literal replication logic, as both companies were found to act similarly in relation to the research questions.

Table 4 summarizes the research results. To map the findings to each research question, the results are identified with a sequential code, linked to the corresponding research question. Additional discussion of the results can be found in Ortiz (2015). The words "construction companies", "program or project managers", and the like are used regarding the findings of the research, and refer only to the construction companies analyzed (A, B, E, F, G, H, I, J).

R1-Q1: Mistrust among contractor's crew members determine time and cost contingency management. The research showed that program and project managers from both $\mathrm{A}$ and $\mathrm{B}$ do not openly discuss contingency management. The Phase 2 survey showed that both companies A and $B$ include hidden time and cost buffers within schedules and budgets. Along this line, during the interviews with $\mathrm{A} 1$ and $\mathrm{B} 1$ (program managers of $\mathrm{A}$ and $\mathrm{B}$ ), both explicitly, and independently stated, that time and cost buffers are hidden in cost and task estimates through greater unit costs, larger bills of materials or longer-than-expected durations. Thus, program manager A1 affirmed: "When scheduling projects, project managers may inflate, in a hidden manner, the duration of certain activities as well as bill of quantities. When budgeting projects, they may inflate, also in a hidden manner, some estimated unit costs". Literature explains that time and cost contingencies can be

Table 3. Characteristics of companies E, F, G, H, I and J in relation to the selection criteria

\begin{tabular}{|c|c|c|}
\hline Non-integrated & Partially integrated & Totally integrated \\
\hline COMPANY H & COMPANY J & COMPANY G \\
\hline Annual revenues: >7,000 M€ & Annual revenues: $500 \mathrm{M} €$ & Annual revenues:100 M€ \\
\hline Competitive contracts $>90 \%$ of the total & Competitive contracts $\sim 40 \%$ of the total & Competitive contracts $\sim 10 \%$ of the total \\
\hline COMPANY I & COMPANY F & COMPANY E \\
\hline Annual revenues: 1,000 M€ & Annual revenues: $15 \mathrm{M} €$ & Annual revenues: $45 \mathrm{M} €$ \\
\hline Competitive contracts $>90 \%$ of the total & Competitive contracts $\sim 25 \%$ of the total & Competitive contracts $\sim 10 \%$ of the total \\
\hline
\end{tabular}


Table 4. Summary of results of the research

\begin{tabular}{|c|c|c|}
\hline Research questions & Research results & Description of results \\
\hline $\begin{array}{l}\text { Q1. What factors determine } \\
\text { contractors' managerial } \\
\text { approach to time and cost } \\
\text { contingency management? }\end{array}$ & $\begin{array}{l}\text { R1-Q1. Mistrust among } \\
\text { contractor's crew members } \\
\text { determine time and cost } \\
\text { contingency management }\end{array}$ & $\begin{array}{l}\text { Time and cost buffers are hidden across schedule and budget } \\
\text { line items } \\
\text { Buffers are often hidden due to the mistrust among program } \\
\text { and project managers }\end{array}$ \\
\hline & $\begin{array}{l}\mathrm{R} 2-\mathrm{Q} 1 . \text { Time and cost } \\
\text { contingencies restraint by project } \\
\text { management objectives }\end{array}$ & $\begin{array}{l}\text { Program managers define project objectives } \\
\text { Project objectives are consciously established to limit the size } \\
\text { of time and cost contingencies } \\
\text { Once project objectives have been established, project } \\
\text { managers are the main decision-makers on contingencies }\end{array}$ \\
\hline $\begin{array}{l}\text { Q2. How do general } \\
\text { contractors price } \\
\text { opportunities? }\end{array}$ & $\begin{array}{l}\text { R1-Q2. Pricing of opportunities } \\
\text { through negative contingencies }\end{array}$ & $\begin{array}{l}\text { Project managers value opportunities through negative } \\
\text { contingencies } \\
\text { Negative contingencies show potential reductions of time and } \\
\text { cost } \\
\text { Construction companies jointly manage negative (i.e., } \\
\text { opportunities-related) and positive (i.e., threats-related) } \\
\text { contingencies }\end{array}$ \\
\hline
\end{tabular}

specifically defined for particular budget lines or scheduled activities (Yeo 1990; Thompson, Perry 1992; Barraza 2010), and/or set up generically as a global percentage of the budget (Baccarini 2004) or schedule (Goldratt 1997). Companies A and B follow the first approach. Project managers of both companies were found to agree with the above statement (except for A2 and B4, who claimed that they never use costs buffers). The researchers also discovered evidence in the written documentation (i.e. cost estimates and schedule) that corroborated the previous statements. Project managers A4, A7, B2, B3 and B5 actually showed the research team two different budget and schedule versions of their current projects - the official version and the actual version. All other project managers confirmed that they prepare also at least two budget and schedule versions, but they did not offer them to the researchers. The project managers confirmed that the official version is shared with other crew members; however, the actual version reflects the personal and unshared view of the project manager and tends to be more ambitious than the official one. The quantitative differences between these two versions are due to the buffers hidden within the official version. The hidden nature of cost buffers was already posed by Ford (2002), which is one of the few references found to discuss the management of costs buffers from the perspective of construction companies during construction phase. Smith and Bohn (1999) and Laryea and Hughes (2011) also described the hidden nature of cost buffers, though within the context of bidding processes. The fact that construction companies set hidden buffers is not new, this research only confirmed the view of those authors, but at this point it is worth discussing why construction companies act in such a way and forego the possibility to set generic, global and explicit buffers during the construction phase. At the beginning of Phase 2 of the research, general managers of A and B stressed that if buffers were explicit, the program managers would remove them.
During the interview that took place within Phase 3, program manager A1 was asked to argue why project managers set hidden buffers. In his answer, he stated: "If I had had to approve a budget or a schedule with explicit buffers, I would have removed them right away, because I would have considered that besides those, the project manager had set up additional hidden buffers". Project manager B1 and all the interviewed project managers of both companies expressed their agreement with Al's assertion. The conclusion is that project managers set hidden and therefore specific buffers to avoid detection from their program managers, which in turn shows that the relationship between project and program managers - as regards at least risk management - includes a level of mistrust.

R2-Q1: Time and cost contingencies restraint by project management objectives. The discussion of the above findings showed that project managers usually prepare two different budget and schedule versions for their projects - the official version and the actual version. On the one hand, the official version is consistent with the official project objectives that program managers set, while the actual budget and schedule version is consistent with the actual project objectives that project managers set. As stated above, the research showed that project and program managers do not openly discuss contingency management. Rather, the program managers consciously limit the initial size of buffers when establishing constraining official project objectives. Indeed, during the kick-off meetings, general managers of companies $\mathrm{A}$ and $\mathrm{B}$ confirmed that program managers usually establish project objectives. Accordingly, A1 stated that when determining time and cost project objectives, program managers explicitly take into consideration the hidden buffers that project managers set up to manage cost and schedule performance. Along this line B1 stressed: "If they know (the program managers) that a certain project manager is more prone to set bigger 
buffers, the program managers establish more ambitious project objectives". A number of project managers expressed similar opinions. For example, B2 stated that: "By setting more or less ambitious official objectives, my supervisors take into consideration the management behaviors of each particular project manager"; whereas A4 pointed out that: "Sometimes official objectives are so tight that there is no room for buffers".

This finding fits the view of Howell et al. (1993) regarding the restrictive nature of project objectives. Howell et al. (1993) considered that project objectives present a dual nature - they are both ends and means. Objectives are ends because they express the expected project outcomes. Likewise, project objectives are means because they provide a decision-making guide for managers. Objectives thereby constrain managers' behavior. In this case, the objectives constrain the sizing of time and cost buffers, objectives define a buffer ceiling. The program managers set the project objectives, but they do not explicitly direct how project managers size time and cost contingency. The practical impact of this finding is that project objectives are set without an explicit and shared valuation of risks, i.e. without previously defining buffers. In other words, project objectives are consciously set to condition buffers, not the other way around.

R1-Q2: Pricing of opportunities through negative contingencies. As previously mentioned, risk is a two-sided concept representing both threats and opportunities. In spite of the relevancy of opportunities management to project success (Hillson 2002; Leach 2003; Godfrey 2004; Molenaar et al. 2010; Laryea, Hughes 2011; PMI 2013), the majority of the literature focuses on the management of threats. Yet, only one effort was found analyzing the connection between opportunities and cost contingencies; indeed, Eldosouky et al. (2014) affirm that contractors should assess not only threats, but also opportunities in order to properly size cost contingency during the bidding processes; nevertheless no references have been found about how general contractors actually manage opportunities during the construction phase. From an operational point of view, this discussion poses another characteristic of buffers - their arithmetical sign. This subject was tacitly presented by Molenaar et al. (2010, p. 8): “...the sum of which (contingency) is added to the base estimate to complete the project cost estimate". Indeed, buffers set up to cover threats have positive arithmetical sign.

Turning to companies A and B, the Phase 2 survey showed that while company B has a corporate opportunities management procedure (in the company's procedural documents, the opportunities are called "unpriced objectives"), company A has no such a kind of procedure. During the interviews that took place in Phase 3, both the program managers and all the interviewed project managers stated that they usually identify, assess and value potentially useful opportunities in order to optimize projects. This was corroborated by a number of reference documents

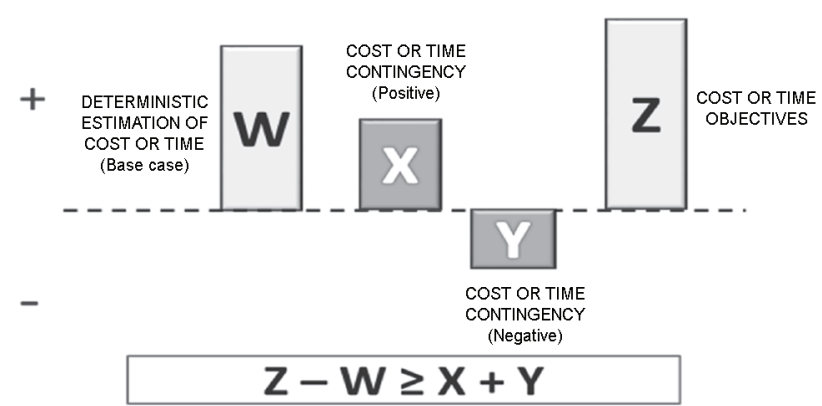

Figure 2. Joint management of positive and negative contingencies

that the authors analyzed. Furthermore, even though company B seems to manage opportunities in a more advanced way than company A, both firms price the opportunities identified in the same way: As less cost and/or less time to completion. This fact was confirmed by both the program managers and all the interviewed project managers of $\mathrm{A}$ and $\mathrm{B}$, as well as being shown in project documents. On the basis on this evidence and inference from the literature, negative time and/or cost contingency are defined as the valuation of opportunities as less time or cost. The sum of negative contingencies is subtracted from the base estimate to complete the project cost estimate.

Summarizing, construction companies set up two different types of time and cost contingencies: positive buffers to hedge threats and negative buffers to capture opportunities. Thus, a negative contingency is defined as a potential reduction of deterministic cost and time estimates. This finding fits in with the Chapman and Ward (2003) approach, who argue that since both opportunities and threats arise throughout construction process, they ought to be jointly managed. Chapman and Ward (2003) build their case on the interactive nature of risks, which are comprised of both opportunities and threats. In this regard, Figure 2 depicts an example project whose risk profile is slightly negative. Rectangles $\mathrm{X}$ and $\mathrm{Y}$ respectively represent the total amount of positive contingency - what is in turn a valuation of project threats - and negative contingency - a valuation of project opportunities. Since the area of rectangle $\mathrm{X}$ is greater than the area of rectangle $\mathrm{Y}$, the impact of threats is greater than the impact of opportunities. Figure 2 also depicts two additional rectangles - W and $\mathrm{Z}$ - whose areas respectively represent the total deterministic cost (or time) estimate and the total cost (or time) to complete the project objective. The equation included in Figure 2 would be the algebraic expression of the constraining effect of the deterministic cost (or time) estimate and cost (or time) project objectives, which as above discussed, implies that the size of cost and time contingency should be set up within the limits of such constraints. At this point, the authors would like to stress that it is not the intent of this research to describe how companies size each of those rectangles, but rather to describe the relationship among them regardless of size. 


\section{Conclusions}

In the construction phase, the construction companies analyzed set hidden and therefore specific, rather than explicit and generic, time and cost contingencies to hedge threats that could jeopardize project success, i.e. positive contingencies. This shows that the relationship among contractor's crew members is based - at least regarding risk management - on mistrust (R1-Q1: Mistrust among contractor's crew members determine time and cost contingency management). At the same time, the research shows that contractors define time and cost contingencies to price opportunities that could improve the chances of project success, thereby providing insight into a previously undescribed form of contingency: the negative contingency (R2-Q1: Pricing of opportunities through negative contingencies). The research also showed that construction companies jointly manage both types of contingency (i.e. positive and negative). These two results supplement and extend to the construction phase of projects and to time contingencies what other authors discovered regarding bidding processes and cost contingencies. Project and program managers are the main decision-makers for contingency management. However, in this research, they were not found to work as a team. Indeed, while program managers set project objectives to consciously constrain the size of contingencies (R2-Q1: Time and cost contingencies restraint by project management objectives), project managers establish the contingency in a hidden manner, revealing an existing mistrust among crew members (R1-Q1: Mistrust among contractor's crew members determine time and cost contingency management). This result expands the above described view, already described in literature, on the constraining nature of project objectives. In addition, this result confirms the role of project managers as decision-makers on contingency management, as well as highlights the active role of program managers on contingency management.

In addition to the above described specific contributions to the body of knowledge, from a broader point of view, the research also contribute to shed light into an issue scarcely discussed in literature: How construction companies manage time and cost contingencies during the execution phase of projects. The research results enable a better understanding of the actual behavior of general contractors, which contributes to paving the way for developing enhanced methods for contingencies management.

More broadly, the results of this research align with and extend research in contingency management. This research shows that the contingency management systems in the analyzed companies contain deficiencies. Literature, as described above, shows that these deficiencies are not exclusive to the analyzed companies and, therefore, they represent opportunities for industry improvement. The companies used hidden and specific time and cost buffers, rather than explicit and generic buffers, as well as the contingency management systems in both companies lack a broad procedural framework. Nonetheless, such short- comings might not result from conscious decisions, but they may be a consequence of the prevailing mistrust among the contractor's team members. In short, this mistrust might well be described as the root cause of those flaws. Tackling such lack of trust is strategic for construction companies. On the basis of these ideas, construction companies studied might well analyze how to overcome such a mistrust-based relationship among their crew members as a way to enhance their competitiveness.

The results of this research, as well as the limitations, open the door to a wide range of future investigation. Further exploration of positive and negative contingency management is particularly noteworthy in this respect. Additional investigation as to how companies constrain contingency management by means of project objectives and how they specifically size contingencies within such constraints are warranted. Even though the research was not completely exhaustive and has some limitations (e.g. the case study sample size and examination in only the Spanish context), the authors can claim the generalization of the results to a specific domain (i.e. the construction phase of civil engineering and building construction projects carried out by large and medium-sized Spanish general contractors with any degree of integration between the developer and the contractor). Such generalization is based on the fact that during Phase 5, the program managers of companies other than $\mathrm{A}$ and $\mathrm{B}$ (companies $\mathrm{E}, \mathrm{F}$, $G, H, I, J)$ expressed their agreement with the research findings as a group. Additional research into similar practices in small companies, subcontractors or other cultural environments would provide for a better understanding of the applicability of the results. Exploring companies outside of the field analyzed would also further the ability to generalize the results.

\section{Acknowledgements}

The authors want to acknowledge the construction companies as well as all the people that participated in this research.

\section{Funding}

The authors did not have any funding to proceed with this research.

\section{Disclosure statement}

The authors state that there is no financial, professional or personal interest or benefit arising from the direct applications of their research.

\section{References}

Asgari, S.; Awwad, R.; Kandil, A.; Odeh, I. 2016. Impact of considering need for work and risk on performance of construction contractors: An agent-based approach, Automation in Construction 65: 9-20.

https://doi.org/10.1016/j.autcon.2016.01.004 
Baccarini, D. 2004. Accuracy in estimating project cost construction contingency - A statistical analysis, in The International Construction Research Conference of the Royal Institution of Chartered Surveyors, 2004, Leeds Metropolitan University, Leeds, UK.

Ballard, G. 2005. Construction: one type of project production system, in The $13^{\text {th }}$ Annual Conference of the International Group for Lean Construction, July 2005, Sydney, Australia, 29-35.

Ballesteros-Pérez, P.; González-Cruz, M. C.; FernándezDiego, M.; Pellicer, E. 2014. Estimating future bidding performance of competitor bidders in capped tenders, Journal of Civil Engineering and Management 20(5): 702-713. https://doi.org/10.3846/13923730.2014.914096

Ballesteros-Pérez, P.; Skitmore, M.; Pellicer, E.; Zhang, X. 2016. Scoring rules and competitive behavior in best-value construction auctions, Journal of Construction Engineering and Management 142(9): 04016035. https://doi.org/10.1061/(ASCE)CO.1943-7862.0001144

Barraza, G. A. 2010. Probabilistic estimation and allocation of project time contingency, Journal of Construction Engineering and Management 137(4): 259-265. https://doi.org/10.1061/(ASCE)CO.1943-7862.0000280

Bhargava, A.; Labi, S.; Chen, S.; Saeed, T. U.; Sinha, K. C. 2017. Predicting cost escalation pathways and deviation severities of infrastructure projects using risk-based econometric models and Monte Carlo simulation, Computer-Aided Civil and Infrastructure Engineering 32: 620-640. https://doi.org/10.1111/mice.12279

Chan, E. H.; Au, M. C. 2009. Factors influencing building contractors' pricing for time-related risks in tenders, Journal of Construction Engineering and Management 135(3): 135-145. https://doi.org/10.1061/(ASCE)0733-9364(2009)135:3(135)

Chapman, C.; Ward, S. 2003. Transforming project risk management into project uncertainty management, International Journal of Project Management 21(2): 97-105. https://doi.org/10.1016/S0263-7863(01)00080-1

Dake, K. 1992. Myths of nature: Culture and the social construction of risk, Journal of Social Issues 48(4): 21-37. https://doi.org/10.1111/j.1540-4560.1992.tb01943.x

de la Cruz, M. P.; Del Caño, A.; de la Cruz, E. 2006. Downside risks in construction projects developed by the civil service: the case of Spain, Journal of Construction Engineering and Management 132(8): 844-852. https://doi.org/10.1061/(ASCE)0733-9364(2006)132:8(844)

Diab, M. F.; Varma, A.; Panthi, K. 2017. Modeling the construction risk ratings to estimate the contingency in highway projects, Journal of Construction Engineering and Management 143(8): 04017041. https://doi.org/10.1061/(ASCE)CO.1943-7862.0001334

Eldosouky, I. A.; Ibrahim, A. H.; Mohammed, H. E. D. 2014. Management of construction cost contingency covering upside and downside risks, Alexandria Engineering Journal 53(4): 863-881. https://doi.org/10.1016/j.aej.2014.09.008

EU. 2003. The new SME definition. User guide and model declaration. Luxembourg: Office for Official Publications of the European Communities.

Ford, D. N. 2002. Achieving multiple project objectives through contingency management, Journal of Construction Engineering and Management 128(1): 30-39. https://doi.org/10.1061/(ASCE)0733-9364(2002)128:1(30)

Godfrey, P. S. 2004. Control of risk a guide to the systematic management of risk from construction. London: Construction Industry Research \& Information Association (CIRIA).
Goldratt, E. M. 1997. Critical chain. Great Barrington, MA: North River Press.

Guest, G.; Bunce, A.; Johnson, L. 2006. How many interviews are enough? An experiment with data saturation and variability, Field Methods 18(1): 59-82. https://doi.org/10.1177/1525822X05279903

Günhan, S.; Arditi, D. 2007. Budgeting owner's construction contingency, Journal of Construction Engineering and Management 133(7): 492-497.

https://doi.org/10.1061/(ASCE)0733-9364(2007)133:7(492)

Hillson, D. 2002. Extending the risk process to manage opportunities, International Journal of Project Management 20(3): 235-240. https://doi.org/10.1016/S0263-7863(01)00074-6

Howell, G. A. 2012. Uncertainty and contingency: implications for managing projects, in Proceedings of the $20^{\text {th }}$ Annual Conference of the International Group for Lean Construction, July 2012, San Diego, CA.

Howell, G. A.; Laufer, A.; Ballard, G. 1993. Uncertainty and project objectives, Project Appraisal 8(1): 37-43. https://doi.org/10.1080/02688867.1993.9726884

Idrus, A.; Nuruddin, M. F.; Rohman, M. A. 2011. Development of project cost contingency estimation model using risk analysis and fuzzy expert system, Expert Systems with Applications 38(3): 1501-1508. https://doi.org/10.1016/j.eswa.2010.07.061

Laryea, S.; Hughes, W. 2011. Risk and price in the bidding process of contractors, Journal of Construction Engineering and Management 137(4): 248-258. https://doi.org/10.1061/(ASCE)CO.1943-7862.0000293

Leach, L. 2003. Schedule and cost buffer sizing: How to account for the bias between project performance and your model, Project Management Journal 34(2): 34-47.

Lofton, W. D.; Monteith, M. D. 2004. Collaborative estimating, in AACE International Transactions, ES11.

Miles, M. B.; Huberman, A. M.; Saldaña, J. 2013. Qualitative data analysis: A methods sourcebook. New York: Sage Pub.

Molenaar, K. R.; Anderson, S. D.; Schexnayder, C. J. 2010. Guidebook on risk analysis tools and management practices to control transportation project costs. Transportation Research Board, Vol. 658, Washington D.C.

Noor, I.; Tichacek, R. L. 2009. Contingency misuse and other risk management pitfalls, Cost Engineering 51(5): 28-33.

Ortiz, J. I. 2015. Risk management during the construction phase of projects using contingencies from the perspective of construction companies: $\mathrm{PhD}$ Dissertation. Universitat Politècnica de València, Valencia.

Ortiz, J. I.; Pellicer, E.; Howell, G. A. 2014. Contingency management in construction projects: A survey of Spanish contractors, in Proceedings of the $22^{\text {nd }}$ Annual Conference of the International Group for Lean Construction, July 2014, Oslo, Norway.

Oviedo-Haito, R. J.; Jiménez, J.; Cardoso, F. F.; Pellicer, E. 2014. Survival factors for subcontractors in economic downturns, Journal of Construction Engineering and Management 140(3): 04013056. https://doi.org/10.1061/(ASCE)CO.1943-7862.0000811

Pellicer, E.; Sanz, M. A.; Esmaeili, B.; Molenaar, K. R. 2016. Exploration of team integration in Spanish multi-family residential building construction, Journal of Management in Engineering 32: 05016012. https://doi.org/10.1061/(ASCE)ME.1943-5479.0000438

Pellicer, E.; Victory, R. 2006. Implementation of project management principles in Spanish residential developments, International Journal of Strategic Property Management 10: 233-248. 
PMI. 2013. A guide to the project management body of knowledge (PMBOK ${ }^{\circledast}$ Guide). Newton Square, Pennsylvania: Project Management Institute.

Querns, W. R. 1989. What is contingency, anyway?, in Transactions of the American Association of Cost Engineers, B.9.1.

Russell, M. M.; Hsiang, S. M.; Liu, M.; Wambeke, B. 2012. Causes of time buffer in construction project task durations, in Proceedings of the $20^{\text {th }}$ Annual Conference of the International Group for Lean Construction, July 2012, San Diego, CA.

Seung, H.; Hyung, K. 2004. Categorical relationship approach as an alternative risk analysis for predicting cost contingency, KSCE Journal of Civil Engineering 8(2): 173-180. https://doi.org/10.1007/BF02829117

Smith, G. R.; Bohn, C. M. 1999. Small to medium contractor contingency and assumption of risk, Journal of Construction Engineering and Management 125(2): 101-108. https://doi.org/10.1061/(ASCE)0733-9364(1999)125:2(101)

Solomon, R. C.; Flores, F. 2001. Building trust in business, politics, relationships, and life. London: Oxford University Press.

Taroun, A. 2014. Towards a better modelling and assessment of construction risk: Insights from a literature review, International Journal of Project Management 32(1): 101-115. https://doi.org/10.1016/j.ijproman.2013.03.004

Taylor, J. E.; Dossick, C. S.; Garvin, M. 2011. Meeting the burden of proof with case-study research, Journal of Construction Engineering and Management 137(4): 303-311. https://doi.org/10.1061/(ASCE)CO.1943-7862.0000283

Teddlie, C.; Tashakkori, A. 2009. Foundations of mixed methods research: Integrating quantitative and qualitative approaches in the social and behavioral sciences. Thousand Oaks: Sage.

Thompson, P.; Perry, J. G. 1992. Engineering construction risks: A guide to project risk analysis and assessment implications for project clients and project managers. London: Thomas Telford.

Woodside, A. G. 2010. Case study research: Theory, methods, practice. Bingley, UK: Emerald Group Pub.

Yeo, K. T. 1990. Risks, classification of estimates, and contingency management, Journal of Management in Engineering 6(4): 458-470. https://doi.org/10.1061/(ASCE)9742-597X(1990)6:4(458)

Yin, R. K. 2009. Case study research: Design and methods. New York: Sage Pub. 